\title{
Effect of an oestrogen antagonist on implantation and uterine leucylnaphthylamidase activity in the ovariectomized hamster
}

\author{
Jayasree Sengupta, B. C. Paria and S. K. Manchanda \\ Department of Physiology, All India Institute of Medical Sciences, New Delhi 110029, India
}

\begin{abstract}
Summary. CI-628 citrate, an oestrogen antagonist, instilled into the uterine lumen of ovariectomized, progesterone-treated hamsters on Day 3 of pregnancy completely prevented implantations. Normal implantations occurred in the contralateral uterine horn which was pierced by a needle and in horns into which saline was instilled. There was less activity of lysosomal leucylnaphthylamidase in implantation sites than in inter-implantation sites and in the tissues of the CI-628 citrate-treated horns.
\end{abstract}

\section{Introduction}

It is well known that in the rabbit, hamster, guinea-pig and monkey, normal implantation of the embryo can occur in the absence of the ovary provided progesterone is given exogenously (Deanesly, 1960; Orsini \& Meyer, 1962; Meyer, Wolf \& Arslan, 1969; Kwun \& Emmens, 1974). It has been suggested that, in some of these species, the preimplantation embryo could be the source of oestrogen which is synthesized or accumulated by the blastocyst (Dickmann, Dey \& Sengupta, 1976; George \& Wilson, 1978; Singh \& Booth, 1978). Hamster morulae and blastocysts have been shown to contain $\Delta^{5}-3 \beta$-hydroxysteroid dehydrogenase and $17 \beta-$ hydroxysteroid dehydrogenase (Dickmann \& Sengupta, 1974).

In the uterus a series of morphological and biochemical events occur which lead to cell death as the blastocyst attaches to and penetrates the uterine epithelial cell layer during implantation. An involvement of lysosomal enzymes in this localized cell death could occur from within the cells by 'programmed cell autolysis' (El-Shershaby \& Hinchliffe, 1975) or be induced by factors released locally from the blastocyst (Sengupta, Roy \& Manchanda, 1979). There are reports of uterine lysosomal enzyme activity during implantation and early decidualization in rats and mice (Moulton, Koenig \& Borkan, 1978; Sengupta et al., 1979) but to our knowledge no such work has been reported for the hamster.

We have therefore investigated whether there is a local need for oestrogen during implantation in the hamster, and analysed the activity of a lysosomal proteolytic enzyme in the uterus during implantation.

\section{Materials and Methods}

Golden hamsters (Mesocricetus auratus) were housed in a windowless, air-conditioned room with lights on from 05:00 to 19:00 h. Young adult, virgin females were mated with fertile males and the day of finding spermatozoa in vagina was designated as Day 1 of pregnancy. On the morning of Day 2, animals were anaesthetized with pentobarbitone sodium $(8 \mathrm{mg} / 100 \mathrm{mg}$ body 
weight) and bilateral ovariectomy was performed with great care to avoid any excess bleeding or injury to the oviducts. The ovaries were inspected for corpora lutea to indicate the number of ovulations. The females were given a daily subcutaneous injection of $0.5 \mathrm{mg}$ progesterone until the end of the experiment.

On Day 3, the animals were allocated to 2 groups and at 20:00 $\mathrm{h}$ they were anaesthetized for exposure of the uteri through a dorsolateral incision. The animals in Group I received an injection of $1.3 \mu \mathrm{l}$ sterile saline $(9 \mathrm{~g} \mathrm{NaCl} / \mathrm{l})$ into one uterine horn while the contralateral horn was only pierced with the needle. Group II animals similarly received $2.6 \mu \mathrm{g}$ CI-628 citrate (Parke Davis Co., U.S.A.) dissolved in $1.3 \mu$ saline in one horn and injection only of the contralateral horn. A 10- $\mu$ Hamilton syringe was used to deliver fluid intraluminally at a very slow rate, with care being exercised to avoid any excess handling of uteri. At 12:00 h on Day 4, animals were killed $15 \mathrm{~min}$ after an injection of $1.0 \%$ Evans' blue dye into the femoral vein. The numbers of distinct blue bands were observed and these areas and the zones between them were quickly excised and frozen immediately at $-20^{\circ} \mathrm{C}$. If there were no blue bands, the uterine horns were flushed with ice-cold $0.9 \%(\mathrm{w} / \mathrm{v}) \mathrm{NaCl}$ to recover any free blastocysts. The uteri were then frozen.

The activity of leucylnaphthylamidase (EC 3.4.1.1) in implantation and inter-implantation zones was assayed on the same day without any storage of the tissues. Enzyme assay was performed on preweighed tissue samples homogenized in ice-cold $0.25 \mathrm{M}$-sucrose at $0^{\circ} \mathrm{C}$ with 3 5 -sec bursts and a $30-\mathrm{sec}$ interval between each burst. Tissues were next centrifuged at $0^{\circ} \mathrm{C}$ for $15 \mathrm{~min}$ at $7000 \mathrm{~g}$. The supernatant was used for enzyme assay. Leucylnaphthylamidase activity was measured by the liberation of naphthylamine from L-leucyl- $\beta$-naphthylamine $\mathrm{HCl}$ (Sigma) measured spectrophotometrically at $580 \mathrm{~nm}$ (Goldberg \& Rutenberg, 1958). The enzyme activity was shown to be linearly related to time. Protein concentrations were estimated by the method of Lowry, Rosebrough, Farr \& Randall (1951). The statistical significance of differences between means was determined by a paired $t$ test.

\section{Results}

The results are given in Table 1. Injection of CI-628 prevented the appearance of blue dye bands and 10 zona-encased and 7 zona-free blastocysts were recovered. Normal implantations occurred in the contralateral horn of Group II animals and in both horns of Group I animals.

Table 1. Effect of CI-628 citrate on implantation and activity of uterine leucylnaphthylamidase activity in ovariectomized progesterone-treated hamsters killed on Day 4

\begin{tabular}{|c|c|c|c|c|}
\hline & \multicolumn{2}{|c|}{ Group I } & \multicolumn{2}{|c|}{ Group II } \\
\hline & $\begin{array}{c}\text { Control } \\
\text { horn }\end{array}$ & $\begin{array}{l}\text { Saline } \\
\text { horn }\end{array}$ & $\begin{array}{c}\text { Control } \\
\text { horn }\end{array}$ & $\begin{array}{c}\text { CI-628 } \\
\text { horn }\end{array}$ \\
\hline No. of hamsters & \multicolumn{2}{|c|}{6} & \multicolumn{2}{|c|}{7} \\
\hline No. of CL & 25 & 30 & 31 & 31 \\
\hline No. of dye-positive sites & 18 & 15 & 21 & 0 \\
\hline \multicolumn{5}{|c|}{ Enzyme activity ( $\mu \mathrm{M}$ naphthylamine $/ \mathrm{h} / \mathrm{mg}$ protein) } \\
\hline Implantation zones & $0.47 \pm 0.5$ & $0.60 \pm 0.04$ & $0.56 \pm 0.06$ & - \\
\hline Inter-implantation zones & $0.81 \pm 0.06^{*}$ & $0.93 \pm 0.08^{*}$ & $0.84 \pm 0.06^{*}$ & - \\
\hline Non-implantation zones & - & - & - & $0.85 \pm 0.06$ \\
\hline
\end{tabular}

Values are mean \pm s.e.m.

* Significantly different from value in implantation zones, $P<0.001$.

The activity of uterine leucylnaphthylamidase was significantly lower in implantation than in inter-implantation sites (Table 1). The value for the CI-628-treated horns was similar to that for 
the inter-implantation areas in the control horns of the same animals and both horns of Group I animals. Enzyme activity was expressed as per $\mathrm{mg}$ protein to avoid problems with the oedema that occurs at implantation.

The effect of Evans' blue dye on enzyme activity in the uterus was also studied because detection of implantation sites by the injection of Evans' blue dye is dependent upon the local increase in vascular permeability at the implantation site. To eliminate the possibility that the localization of blue dye at the implantation site influenced the assay of leucylnaphthylamidase, ovariectomized hamsters were injected i.p. with oestradiol $(20 \mu \mathrm{g})$ to induce maximal uterine vascular permeability. Injection of Evans' blue $6 \mathrm{~h}$ later had no significant effect upon the enzyme activity which was $0.86 \pm 0.05$ units compared with $0.87 \pm 0.08$ units in saline-injected control uteri ( 1 unit $\equiv \mu \mathrm{M}$ naphthylamine $/ \mathrm{h} / \mathrm{mg}$ protein).

\section{Discussion}

In virgin hamsters, implantation occurs at about 12:00 $\mathrm{h}$ on Day 4 and is accompanied by increased uterine vascularity as shown by dye-positive bands and morphological changes in trophoblast and uterine epithelial cells (Parkening, 1976). Implantation can occur in hamsters in the presence of low serum oestrogen levels (Orsini \& Meyer, 1962; Harper, Dowd \& Elliot, 1969), but the present study suggests that there is a local need for oestrogen: blastocysts of normal appearance were recovered from CI-628-treated uterine horns although implantation had occurred in saline-injected or needle-pricked horns.

Because the hamsters had been ovariectomized on Day 2, serum oestrogen concentrations were low and the only possible sources of oestrogen to be suppressed by CI-628 were the blastocysts or adrenals. Harper et al. (1969) have shown that implantations occurred even in adrenalectomized and ovariectomized animals treated with progesterone, and so the blastocysts would appear to be the most likely source.

In rabbits, implantation was inhibited when oestrogen receptors in the uterine endometrium and blastocyst were bound by intraluminally injected CI-628 (Bhatt \& Bullock, 1974; Dey, Dickmann \& Sengupta, 1976). In the hamster, the blastocyst oestrogen could be derived from de-novo synthesis (Dickmann \& Sengupta, 1974) or sequestered steroids from the surrounding uterine milieu (Borland, Erickson \& Ducibella, 1977; Singh \& Booth, 1978; Angle \& Mead, 1979) and delivered locally to uterine endometrial cells to initiate implantations.

Ultrastructural studies of implantation in the hamster have shown that epithelial cell autolysis precedes invasion by trophoblast and phagocytosis and engulfment of epithelial cells (Parkening, 1976). In the mouse, autolysis of the uterine epithelium also precedes trophoblastic invasion (El-Shershaby \& Hinchliffe, 1975). It is likely that epithelial cell lysosomes may be involved in the initiation of cell death. In the hamster, a large number of lysosomes can be identified electron microscopically in trophoblast and uterine epithelium at the time of embryo attachment and implantation (Parkening, 1976) and implantation in several species has been associated with a diversity of changes in uterine ly sosomal enzyme activities (Abraham, Hendy, Dougherty, Fulfs \& Golberg, 1970; Sengupta et al., 1979). A decrease in leucylnaphthylamidase has been reported (Van Hoorn \& Denker, 1975; Sengupta et al., 1979). Decidualization is associated with a diversity of changes in uterine lysosomal enzymes and these are evident $48 \mathrm{~h}$ after embryo attachment and dye uptake (Moulton, 1974; Moulton et al., 1978). In the present study we have shown that implantation is associated with changes in the lysosomal peptidase leucylnaphthylamidase.

This work was supported by grants from the Indian Council of Medical Research to J.S.G. and the Family Planning Foundation of India to SKM. We thank the Parke Davis Co., U.S.A. for their generous gift of CI-628 citrate. 


\section{References}

Abraham, R., Hendy, R., Dougherty, W.J., Fulfs, J.C. \& Golberg, L. (1970) Participation of lysosomes in early implantation in the rabbit. Expl molec. Pathol. 13, 329-345.

Angle, M.J. \& Mead, R.A. (1979) The source of progesterone in preimplantation rabbit blastocysts. Steroids 33, 625-637.

Bhatt, B.M. \& Bullock, D.W. (1974) Binding of oestradiol to rabbit blastocysts and its possible role in implantation. J. Reprod. Fert. 39, 65-70.

Borland, R.M., Erickson, G.F. \& Ducibella, T. (1977) Accumulation of steroids in rabbit preimplantation blastocysts. J. Reprod. Fert. 49, 219-224.

Deanesly, R. (1960) Implantation and early pregnancy in ovariectomized guinea-pigs. J. Reprod. Fert. 1, 242-248.

Dey, S.K., Dickmann, Z. \& Sengupta, J. (1976) Evidence that the maintenance of early pregnancy in the rabbit requires blastocyst estrogen. Steroids $\mathbf{2 8}$, $481-485$.

Dickmann, Z. \& Sengupta, J. (1974) $\Delta^{5}-3 \beta$. hydroxysteroid dehydrogenase and estradiol-17 $\beta$ hydroxy steroid dehydrogenase activity in preimplantation hamster embryos. Devl Biol. 40, 196-198.

Dickmann, Z., Dey, S.K. \& Sengupta, J. (1976) A new concept: control of early pregnancy by steroid hormones originating in the preimplantation embryo. Vitams Horm. 34, 215-242.

El-Shershaby, A.H. \& Hinchliffe, J.R. (1975) Epithelial autolysis during implantation of the mouse blastocyst: an ultrastructural study. J. Embryol. exp. Morph. 33, 1067-1080.

George, F.W. \& Wilson, J.D. (1978) Estrogen formation in the early rabbit embryo. Science, N.Y. 199, $200-201$

Goldberg, J.A. \& Rutenberg, A.M. (1958) The colorimetric determination of leucine-aminopeptidase in urine and serum of normal subjects and patients with cancer and other diseases. Cancer 11, 283-291.

Harper, M.J.K., Dowd, D. \& Elliot, A.S.W. (1969)
Implantation and embryonic development in the ovariectomized-adrenalectomized hamster. Biol. Reprod. 1, 253-257.

Kwun, J.K. \& Emmens, C.W. (1974) Hormonal require ment for implantation and pregnancy in the ovariectomized rabbit. Aust. J. biol. Sci. 27, 275283.

Lowry, O.H., Rosebrough, N.J., Farr, A.L. \& Randall, R.J. (1951) Protein measurement with Folin-Phenol reagent. J. biol. Chem. 193, 265-275.

Meyer, R.K., Wolf, R.C. \& Arslan, M. (1969) Implantation and maintenance of pregnancy in progesterone treated ovariectomized monkeys (Macaca mulatta). Proc. 2nd Int. Congr. Primat. 2, 30-35.

Moulton, B.C. (1974) Ovum implantation and uterine lysosomal enzyme activity. Biol. Reprod. 10, 543548.

Moulton, B.C., Koenig, B.B. \& Borkan, S.C. (1978) Uterine lysosomal enzyme activity during ovum implantation and early decidualization. Biol. Reprod. $19,167-170$.

Orsini, M.W. \& Meyer, R.K. (1962) Effect of varying doses of progesterone on implantation in the ovariectomized hamster. Proc. Soc. exp. Biol. Med. 110, 713-715.

Parkening, T.A. (1976) An ultrastructural study of implantation in the golden hamster. II. Trophoblastic invasion and removal of the uterine epithelium. J. Anat. 122, 211-230.

Sengupta, J., Roy, S.K. \& Manchanda, S.K. (1979) Hormonal control of implantation: a possible role of lysosomal function in the embryo-uterus interaction. J. Steroid Biochem. 11, 729-744.

Singh, M.M. \& Booth, W.D. (1978) Studies on the metabolism of neutral steroids by preimplantation rabbit blastocysts in vitro and the origin of blastocyst oestrogen. J. Reprod. Fert. 53, 297-304.

Van Hoorn, G. \& Denker, H.W. (1975) Effect of the blastocyst on a uterine amino acid arylamidase in the rabbit. J. Reprod. Fert. 45, 359-362. 